*Doutora em Direito pela Universidade Federal do Paraná (UFPR). Mestre em Direito pela Universidade Federal do Paraná (UFPR). Especialista em Direito Processual Tributário pela Universidade de Brasilia (UNB). Especialista em Direito e suas Relações com a Ecologia pela Pontifícia Universidade Católica do Paraná (PUCPR). Especialista em Lingua Inglesa pela Pontifícia Universidade Católica de Minas Gerais (PUCMG). Bacharel em Direito pela Federação das Escolas Superiores de Ilhéus e Itabuna (FESPI). Licenciada em Letras pela Universidade Federal do Paraná (UFPR). Email: glacy.botelho@uol. com.br

** Mestre em Direito, Relações Internacionais e Desenvolvimento pela Pontifícia Universidade Católica de Goiás (PUCGO). Especialista em Direito Constitucional e Administrativo pela Pontifícia Universidade Católica de Goiás (PUCGO). Especialista em Direito Civil e Processo Civil pela Faculdade Anhanguera de Ciências Humanas (FACH). Bacharel em Direito pela Pontificia Universidade Católica de Goiás. (PUCGO). Email: sinnara@gmail.com

\section{Responsabilidade Do Transportador Pelas INFraÇões No TrânsITO AdUANEIRo}

\author{
Responsability Of The Carrier For Customs \\ TRANSPORT INFRINGEMENTS
}

Como citar: BOTELHO, Glacy Odete Rachid. CAMPOS, Sinara de Freitas Elias. Responsabilidade do transportador por infrações no transporte aduaneiro. Scientia Iuris, Londrina, v. 24, n. 1, p. 186-203, mar. 2020. DOI 10.5433/21788189.2020v24n1p186. ISSN 2178-8189.

Resumo: O presente trabalho traz a estudo o instituto da responsabilidade tributária relacionada ao trânsito de mercadorias no território nacional, quando efetuado na modalidade de Trânsito Aduaneiro. A concessão do regime atende a algumas peculiaridades, pois foge à regra geral do regime comum de importação e exportação, que, salvo exceções legais, implica no pagamento dos impostos quando da saída ou entrada de mercadoria no território nacional. Concedido o benefício após cumpridas as exigências legais, há a permissão para o transporte destas mercadorias, de um recinto alfandegado a outro, com suspensão do pagamento de tributos, devendo as mercadorias despachadas em trânsito aduaneiro chegar ao local do destino, invioladas, com os lacres sem sinal de alteração. No caso de tal não ocorrer, a legislação prevê penalidades a serem aplicadas ao transportador, podendo mesmo haver a perda da mercadoria e do veículo, bem como a execução do termo de garantia. Com o Trânsito Aduaneiro o desembaraço aduaneiro é simplificado, o que facilita as operações de transporte de carga e os custos de armazenagem se tornam mais competitivos.

Palavras-chave: Aduana. Trânsito Aduaneiro. Transportador. Penalidades. Responsabilidade.

Abstract: The present study brings to the study the institute of tax responsibility related to the transit of goods in the national territory, when carried out in the modality of Customs Transit. The concession of the scheme meets certain peculiarities, 
because it escapes the general rule of the common import and export regime, which, with legal exceptions, implies the payment of taxes when the goods leave or enter national territory. Once the legal benefits have been granted, there is permission to transport these goods, from one customs office to another, with suspension of the payment of taxes, and the goods dispatched in customs transit arrive at the place of destination, inviolate, with the seals without change. If this does not occur, the legislation provides penalties to be applied to the carrier, and may even loss of the merchandise and the vehicle, as well as the execution of the warranty term. With Customs Transit customs clearance is simplified, which facilitates freight transport operations and storage costs become more competitive.

Keywords: Customs. Customs Transit. Conveyor. Penalties. Responsibility. 


\section{INTRODUÇÃO}

O Imposto sobre a Importação de produtos estrangeiros, um dos tributos mais antigos do mundo e também do Brasil, ${ }^{1}$ é um imposto federal, real, direto, previsto na Constituição Federal de 1988, em seu artigo 153, inciso I, e suas normas gerais estão estipuladas nos artigos 19 a 22, do Código Tributário Nacional - CTN. É conhecido como Tarifa Aduaneira ou Tarifa das Alfândegas. Já o Imposto de Exportação para o estrangeiro de produtos nacionais ou nacionalizados, também de competência da União, encontra seu fundamento no inciso II, do mesmo artigo da Carta Magna, e os artigos 23 a 28, do referido CTN, o normatizam. Ambos fazem parte do grupo denominado de tributos do comércio exterior.

Como todo tributo, foram ambos, inicialmente, criados para servir de fonte de arrecadação para o Estado, muito embora possuam, atualmente, também uma função interventiva, apresentandose como importante instrumento de política econômica, atuando na proteção à indústria nacional, quando utilizados com fins extrafiscais.

No período em que a vida econômica se resumia entre exportar matérias-primas e alimentos e importar produtos manufaturados, como bem apontou Osíres Lopes Filho, o Imposto de Importação teve como principal finalidade proporcionar recursos ao fisco, finalidade esta justificada pelo liberalismo econômico. (LOPES FILHO, 1984, p. 27)

Introduzida a industrialização, iniciou-se o conflito entre a nova classe industrial emergente, que buscava, avidamente, instrumentos de amparo e fomento e o setor tradicional, formado pela classe agrícola produtora de bens primários e os comerciantes vinculados ao setor externo. Passa-se, então, à utilização do Imposto de Importação como meio de proteção e seu uso, como instrumento da política econômica, o situa no campo da extrafiscalidade.

Como fonte de arrecadação para o tesouro nacional, tal tributo tem como contribuinte o importador ou quem a lei a ele equiparar, pessoa física ou jurídica, regularmente estabelecida ou não, podendo também ser considerado contribuinte o arrematante de produtos apreendidos ou abandonados. "O contribuinte só poderá ser a pessoa (jurídica ou natural) que realizar a importação ou praticar atos pertinentes à aquisição direta de produtos estrangeiros, como decorrência lógica e natural da materialidade disposta na Constituição." (MELO, 2012, p. 55). ${ }^{2}$

É suficiente, para sua incidência, a introdução do produto no território nacional, com o ânimo de aqui permanecer. Assim, a entrada de mercadoria estrangeira no território nacional, visando apenas utilizar o espaço brasileiro como meio de passagem para outro país, por não ter o ânimo de aqui permanecer, não se incorporando à economia interna, não configura importação,

1 As primeiras alfândegas foram instaladas no Brasil a partir de 1549, com a chegada do primeiro governadorgeral. O primeiro imposto aduaneiro importante foi cobrado no século XVII, sob o nome de Dízima da Alfândega abrangendo a importação e exportação de alguns produtos. A partir de 1808, a arrecadação das alfândegas serviu de sustentáculo do Poder Público no Brasil. Na Constituição de 1891, sua previsão estava contida no artigo $7^{\circ}$, inciso I, sendo a União competente para criá-lo.

2 No plano infraconstitucional, o art. 22, do Código Tributário Nacional, estabelece que contribuinte do imposto é (I) importador ou quem a lei a ele equiparar; e (II) o arrematante de produtos apreendidos ou abandonados. A legislação ordinária vigente (Dec.-lei $n^{\circ} 37 / 1966$, art. 31, com a redação do Dec.-lei no 2.472/1988, e Dec. No 6.759/2009, art. 104) dispôs que é contribuinte (I) o importador, assim considerado qualquer pessoa que promova a entrada de mercadoria estrangeira no território aduaneiro; (II) o destinatário da remessa postal internacional indicado pelo respectivo remetente; e (III) o adquirente de mercadoria entrepostada. 
não estando sujeito a este imposto.(PAULSEN, 2018, p. 395-396) No entanto, para tal, deve obedecer as regras do Regime Aduaneiro Especial de Trânsito Aduaneiro. ${ }^{3}$

O Imposto de Exportação, por sua vez, é de feição extrafiscal pois "sua finalidade envolve mais do que arrecadar dinheiro para a União: serve como um importante instrumento de controle do Estado na economia." (CARNEIRO, 2018, p. 440) O regime de Trânsito Aduaneiro também pode ser aplicado à exportação de mercadorias nacionais ou nacionalizadas.

Nesse estudo far-se-á a análise do Trânsito Aduaneiro, levantando os critérios legais para sua concessão, os beneficiários do regime e as regras que devem ser cumpridas durante o trânsito. Ainda, não sendo estas obedecidas, buscar-se-á identificar as penalidades a serem aplicadas e a responsabilidade no caso de se detectar infração à legislação aduaneira que rege este regime. Para tal mister utilizou-se o método dedutivo, com pesquisa na legislação pertinente e na bibliografia especializada.

\section{REGIMES ADUANEIROS ESPECIAIS}

Os regimes aduaneiros especiais podem ser definidos a partir da apresentação de duas características: a) são regimes tributários diferenciados, aplicados nas operações de comércio exterior em que a tributação na importação ou exportação se dá de forma diferenciada dos regimes comuns; b) algumas vezes, a concessão, pela autoridade administrativa aduaneira desses regimes, implica, também, em distinções no tocante à fiscalização aduaneira de produtos que entram e saem do território nacional (FOLLONI, 2005, p. 184). Estes regimes disciplinam exceções, afastandose da regra geral de tributação no comércio exterior, que envolve tanto a importação como a exportação.

São considerados como sendo um conjunto de normas e procedimentos relativos à fiscalização e ao controle realizados pela Secretaria da Receita Federal do Brasil, nas operações de entrada e de saída de mercadoria, do território aduaneiro. ${ }^{4}$ Reza a legislação pertinente que por seu intermédio pode haver concessão de suspensão, isenção ou restituição de tributos do comércio exterior.

Segundo a lição de Liziane Angelotti Meira (2002, p. 41) as distinções destes regimes em relação ao regime comum de importação e exportação, se dá "em decorrência de incentivos fiscais concernentes aos impostos sobre o comércio exterior e de controle aduaneiro em relação aos bens objeto da operação."

Apresentam três características fundamentais: a) suspensão da exigibilidade tributária; b) prazo e condições de permanência da mercadoria no regime; c) garantia dos tributos suspensos. As mercadorias objeto dos regimes aduaneiros especiais podem, ou não, ser despachadas para consumo.

$3 \mathrm{O}$ art. $1^{\circ}$ do Decreto-Lei $n^{\circ} 37 / 66$, em seu $\S 4^{\circ}$, ainda deixa claro que não incide o Imposto de Importação sobre mercadoria estrangeira "destruída sob controle aduaneiro, sem ônus para a Fazenda Nacional antes de desembaraçada" e em "trânsito aduaneiro de passagem, acidentalmente destruída", tudo nos termos dos seus incisos I e II, com a redação dada pelas Leis $\mathrm{n}^{\circ} \mathrm{s} 10.833 / 03$ e 12.350/10.

4 Decreto $\mathrm{n}^{\mathrm{o}} 6.759 / 2009$ - Art. $2^{\circ}$. O território aduaneiro compreende todo o território nacional. 
De acordo com o tratamento dado às importações e exportações, classificam-se os Regimes Aduaneiros como sendo:

a) Comuns ou gerais: neste regime, os fatos submetidos à incidência do imposto não gozam de nenhum benefício ou tratamento especial na exportação ou importação, sujeitando-se ao conjunto de regras e princípios que regulam a generalidade dos fatos submetidos à incidência dos impostos;

b) Especiais, econômicos ou suspensivos: têm como peculiaridade o fato de consistirem exceção à regra geral do Imposto de Importação, caracterizando-se pela diversidade dos seus objetivos, variedade de mecanismos e pela natureza jurídica distinta que apresentam entre si. Sua finalidade precípua não é a destinação da mercadoria ao consumo. Também diz respeito ao regime aduaneiro que permite o benefício da movimentação de mercadoria no território nacional com suspensão ou isenção de tributos incidentes nas operações de comércio exterior. São exemplos desta modalidade: o Trânsito Aduaneiro, o Drawback, a Admissão Temporária, a Exportação Temporária e o Entreposto Aduaneiro.

A finalidade da utilização dos regimes aduaneiros especiais é servir de instrumento para o incremento das exportações e o aumento da competitividade do produto final no mercado externo, uma vez que os produtos beneficiados, desonerados da carga tributária comum às importações, agregam-se ao processo produtivo de um país, possibilitando o barateamento de custos. Servem, ainda, na importação, para a agilização da economia, com evidente saldo positivo para a sociedade como um todo, por intermédio do desenvolvimento das atividades comerciais, de transporte, mão de obra, dentre outras.

O presente trabalho tem enfoque específico nas atividades do Trânsito Aduaneiro, buscando analisar a responsabilidade tributária e as penalidades aplicáveis em caso de infrações administrativas e fiscais.

\subsection{Trânsito aduaneiro}

Uma das espécies de Regime Aduaneiro Especial, o Trânsito Aduaneiro permite o transporte de mercadoria, sob controle aduaneiro, de um ponto a outro do território aduaneiro, com suspensão de tributos, conforme definido no artigo 315, do Regulamento Aduaneiro Brasileiro (Decreto $n^{0}$ 6.759/2009)

Por suas próprias características, o trânsito é efêmero, com finalidade de ter pouca duração, já que apenas permite a passagem da mercadoria pelo território nacional, tendo como finalidade um posterior despacho para consumo, uma introdução em outro regime especial ou saída para o exterior, quando se tratar de trânsito internacional.

Em relação ao fato gerador do Imposto de Importação, o artigo 19, do Código Tributário Nacional dispõe: “Art. 19. O imposto de competência da União, sobre a importação de produtos estrangeiros tem como fato gerador a entrada destes no território nacional." Considera-se ocorrido

5 Art. 43, Decreto-lei no 37/66. 
o fato gerador, como regra, na data do registro da declaração de importação (aspecto temporal) realizado eletronicamente através do Sistema Integrado de Comércio Exterior (Siscomex) (PAULSEN, 2018, p. 397).

Logo, no regime comum de tributação sobre o comércio exterior, o Imposto de Importação incide, em regra, ao se efetuar o registro da declaração de importação, quando se trata de produtos despachados para consumo. Na hipótese de regimes aduaneiros especiais, o produto é despachado para admissão em regime aduaneiro especial, não havendo despacho para consumo, e, como não há despacho para consumo, não há incidência tributária. No caso em tela, far-se-á a admissão no regime de Trânsito Aduaneiro. (FOLLONI, 2005, p. 188-189)

A natureza jurídica do regime é de suspensão da exigibilidade do crédito tributário. A norma incide, e devido a este fato, o sujeito passivo declara a intenção de operar no regime, firmando o termo de responsabilidade, e a possibilidade de constituição do crédito tributário pelo lançamento é suspensa.

Classificar o trânsito aduaneiro como regime suspensivo não tem sido bem aceito por certos autores, isto porque, para haver suspensão de tributos, segundo o CTN, é necessário ter havido seu prévio lançamento, constituindo o crédito tributário (DIALLO, 2001, p. 81). Ocorre, no caso, a suspensão da exigibilidade do crédito antes mesmo de sua constituição. Mas, ainda assim, a maioria da doutrina continua considerando-o um regime suspensivo. James Marins se refere a uma “suspensão preventiva”. Neste caso, ainda não houve a formalização que constituirá o crédito e o que se suspende é a própria possibilidade de constituição do crédito tributário, pelo lançamento. (MARINS, 2017, p. 396-397)

Entende-se que o regime subsiste do local de origem ao local de destino e, desde o momento do desembaraço para trânsito aduaneiro pela repartição de origem até o momento em que a repartição de destino certifique a chegada da mercadoria. A exemplificar, uma mercadoria que entre no Brasil pelo porto do Rio de Janeiro, destinando-se a outro local, como o porto seco de Anápolis, sendo beneficiária deste regime, apenas serão cobrados os tributos incidentes sobre a importação, quando ocorrer o despacho aduaneiro para consumo, no porto de Anápolis e não na sua entrada no porto do Rio de Janeiro.

O trânsito aduaneiro sofre controle fiscal do ponto inicial do itinerário de transporte da mercadoria (local de origem) até o seu local de destino (ponto final do itinerário), onde será processada sua conclusão, pela autoridade fiscal da Receita Federal do Brasil de destino.

\subsubsection{Modalidades de operações para o trânsito aduaneiro}

O Regulamento Aduaneiro estabelece as seguintes modalidades: ${ }^{6}$

A) Trânsito de Importação: é o transporte de mercadoria procedente do exterior, do ponto de descarga no território aduaneiro até o ponto onde deva ocorrer outro despacho (liberação aduaneira da mercadoria), ficando, no trajeto, sob controle fiscal, com suspensão de tributos.

6 Artigo 253 e 254, Regulamento Aduaneiro. 
Deve ser transportada sob Trânsito Aduaneiro porque é mercadoria importada que ainda não foi desembaraçada. Neste caso, a mercadoria proveniente do exterior chega a um local alfandegado de zona primária, ${ }^{7}$ mas o importador, por motivos de logística, ou por buscar uma taxa mais barata, tem interesse que o produto seja liberado em outro local alfandegado, podendo ser, por exemplo, o de sua região fiscal. Também se enquadra nesta classificação a mercadoria procedente do exterior, transportada por veículo em viagem internacional até o ponto em que se verificar a descarga.

B) Trânsito de Exportação: refere-se a trânsito de mercadoria nacional ou nacionalizada, verificada ou despachada para exportação, do local de origem ao local de destino, para embarque ou armazenamento em área alfandegada, para posterior embarque. É também chamado de Trânsito de Saída.

C) Trânsito de Reexportação: operação de transporte de mercadoria despachada para reexportação ${ }^{8}$ do local de origem ao local de destino, para embarque em veículo com destino ao exterior ou armazenamento em área alfandegada, para posterior embarque.

D) Trânsito de Passagem: trata-se de passagem pelo território aduaneiro nacional de mercadoria procedente do exterior e a ele destinada. Por acordos internacionais, o Brasil pode permitir essa passagem sem que haja a incidência de tributos, uma vez que a mercadoria não está destinada a permanecer no território nacional.

E) Trânsito de Transferência: ocorre quando a mercadoria for transportada de um recinto alfandegado a outro. Exemplo: transferência de mercadoria de um ponto de fronteira alfandegado a um entreposto aduaneiro, para ali ser, posteriormente, liberada.

F) Trânsito com Procedimento Simplificado: Inclui-se na modalidade de trânsito de passagem, devendo ser objeto de procedimento simplificado, podendo ser:

i) transporte de materiais de uso, reposição, conserto, manutenção e reparo destinados a embarcações, aeronaves e outros veículos estrangeiros, estacionados ou de passagem pelo território aduaneiro;

ii) o transporte de bagagem acompanhada de viajante em trânsito; e,

iii) o transporte de partes, peças e componentes necessários aos serviços de manutenção e reparo de embarcações em viagem internacional.

\subsection{Despacho para trânsito}

Para que se possa iniciar o Trânsito Aduaneiro, existem exigências apontadas no Regulamento Aduaneiro. Assim, o despacho de Trânsito Aduaneiro é processado com base na Declaração de Trânsito Aduaneiro - DTA, na qual é formulado o pedido de concessão e aplicação

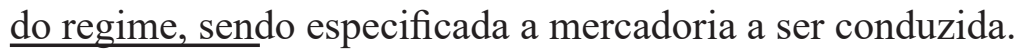

7 A zona primária consiste em toda área demarcada pela autoridade aduaneira local, que tem jurisdição sobre um ponto de entrada ou de saída de veículos, podendo ser um aeroporto, um porto ou uma passagem de fronteira. Ela consiste na parte interna de portos, aeroportos, recintos da alfândega e locais habilitados na fronteira terrestre pela autoridade aduaneira para operações de carga e descarga de mercadorias, ou embarque e desembarque de passageiros, vindo ou indo ao exterior.

$8 \mathrm{O}$ termo reexportação refere-se ao fato de um país, território, região ou cidade importar produtos e exportálos em seguida. Geralmente os produtos reexportados não sofrem qualquer tipo de processo para agregar valor (industrialização), ou seja, são vendidos como foram comprados. 
A pessoa competente para conceder o regime de Trânsito Aduaneiro é o chefe da repartição, sob cuja jurisdição está a mercadoria, ou a quem ele delegar competência. A concessão do regime só se efetiva com o desembaraço da mercadoria.

A autoridade administrativa ao autorizar o regime deverá fixar: a) o itinerário; b) o prazo para execução da operação; c) prazo para comprovação da chegada dos volumes ao local de destino; d) as cautelas fiscais julgadas necessárias.

A Secretaria da Receita Federal, em ato normativo, poderá vedar a concessão do regime para determinadas mercadorias, por motivo de ordem econômica, fiscal ou por outras razões relevantes. É vedada, como exemplo, a concessão do regime a uísque e cigarros, procedentes do exterior e destinados ao Paraguai.

Certas mercadorias, em razão de seus componentes constitutivos, ou de sua natureza ou finalidade, não poderão transitar no território nacional sem prévia autorização dos órgãos competentes, como ocorre no caso de entorpecentes, explosivos, material bélico e radioativo. Desta forma, se a mercadoria estiver sujeita ao controle de outro órgão da Administração Pública, a concessão do regime está condicionada à liberação prévia deste órgão.

\subsubsection{Espécies de declaração de trânsito aduaneiro}

A solicitação do Trânsito Aduaneiro deve ser feita por intermédio da inserção dos dados no Sistema Integrado do Comércio Exterior, módulo trânsito (SISCOMEX Trânsito), efetuando-se a Declaração de Trânsito Aduaneiro que se enquadra na situação desejada pelo usuário.

O despacho de trânsito aduaneiro será processado com base em uma das seguintes declarações: Declaração de Trânsito Aduaneiro (DTA), Manifesto Internacional de Carga Declaração de Trânsito Aduaneiro (MIC-DTA), Conhecimento-Carta de Porte Internacional Declaração de Trânsito Aduaneiro (TIF-DTA), Declaração de Trânsito de Transferência - DTT, Declaração de Transbordo Internacional - DTI, Declaração de Trânsito de Contêiner - DTC, a depender da situação.

Cada documento acima apontado tem aplicação própria para uma das situações distintas. Deixaremos de explicitá-los por fugir ao escopo do presente trabalho.

\subsection{DO TRANSPORTE DAS MERCADORIAS}

Referindo-se ao transporte das mercadorias, aponta Sosa:

As operações de trânsito aduaneiro, no que respeita ao transporte propriamente dito, serão efetuadas por empresas transportadoras habilitadas pela Secretaria da Receita Federal. A habilitação é pleiteada junto ao órgão jurisdicionante, inclusive para efeitos de renovação das habilitações vincendas. No exame a autoridade considerará o interesse administrativo assim como a idoneidade, tradição e 
situação patrimonial do prestador de serviço de transporte (SOSA, 1995, p. 232).

Assim, a empresa transportadora deve estar previamente habilitada para o transporte de mercadorias em regime de Trânsito Aduaneiro, conforme dispõe o artigo 322, do Regulamento Aduaneiro, sendo essa habilitação outorgada, em caráter precário, pela Secretaria da Receita Federal do Brasil. ${ }^{9}$

O transporte para passagem de mercadorias pelo país está condicionada, bem como nos despachos de importação, ao controle administrativo, sujeito à liberação por outros órgão da Administração Pública, como o Ministério do Exército, no caso de armas de fogo, e do Ministério da Agricultura, Pecuária e Abastecimento, em se tratando de produtos que possam trazer algum risco de contaminação.

Ao ser concedido o regime, será realizada a conferência da mercadoria na presença do beneficiário do regime e do transportador, quando se identificará o beneficiário, a mercadoria, verificando-se todas as informações sobre sua natureza e quantificação.

\subsection{Beneficiários do regime de trânsito aduaneiro}

O artigo 321 do Regulamento Aduaneiro aponta como beneficiários do regime de Trânsito Aduaneiro:
a) o importador;
b) o exportador;
c) o depositante: fiel depositário, responsável pelos armazéns alfandegários, para onde as mercadorias irão transitar, seja de natureza privada ou pública; d) o representante, no País, do importador ou exportador domiciliado no exterior;
e) o permissionário ou concessionário de recinto alfandegado;
f) o operador de transporte multimodal;
g) o transportador;
h) o agente unitizador e desunitizador de carga.

A concessão do Trânsito Aduaneiro aos beneficiários implica na obrigação de transportar a mercadoria devidamente lacrada, em container ou não, do local de origem ao local de destino, e entregá-la intacta, da mesma forma em que foi desembaraçada para o trânsito, sendo este encerrado após a verificação, pela autoridade administrativa do local de destino, tendo constatado a inexistência de qualquer infração durante o trânsito. Os beneficiários do regime deverão cumprir com as exigências da lei aduaneira relativas a este regime.

\subsection{GARANTIA}

9 Art. 322. A habilitação das empresas transportadoras será feita previamente ao transporte de mercadorias em regime de trânsito aduaneiro e será outorgada, em caráter precário, pela Receita Federal do Brasil.

$\S 1^{\circ}$ Para concessão ou renovação da habilitação, serão levados em conta fatores direta ou indiretamente relacionados com os aspectos fiscais, a conveniência administrativa, a situação econômico-financeira e a tradição da empresa transportadora, respeitadas as atribuições dos órgãos competentes em matéria de transporte. (Regulamento Aduaneiro) A habilitação se dará mediante solicitação de cadastramento no Siscomex Trânsito e apresentação do Termo de Responsabilidade para Trânsito Aduaneiro (TRTA). (art. $9^{\circ}$, IN SRF n 248, de 2002) 
Na unidade da Receita Federal em que for concedido o Trânsito Aduaneiro será exigida a prestação de garantia pelo transportador, formalizada por meio do aditivo ao TRTA (Termo de Responsabilidade para Trânsito Aduaneiro), a ser anexado ao referido processo administrativo, para assegurar o cumprimento das obrigações fiscais suspensas.

A prestação da garantia ${ }^{10}$ será válida após sua aceitação e inclusão no sistema pelo servidor responsável. Esta pode ser efetuada sob a forma de depósito em dinheiro, fiança idônea ou seguro aduaneiro em favor da União, a critério do transportador.

Prevê a legislação infralegal em vigor (Instrução Normativa SRF no 248/2002 com alterações posteriores) sua dispensa em casos que enumera, dentre os quais na hipótese de o beneficiário do regime ser concessionário ou permissionário de recinto alfandegado de destino, na condição de depositário, e a de o transportador possuir patrimônio líquido superior a $\mathrm{R} \$$ 2.000.000,00 (dois milhões de reais).

A parcela da garantia necessária à cobertura de cada operação de trânsito será de cem por cento do montante dos tributos suspensos. A garantia prestada cobrirá todas as ocorrências dentro de sua vigência, mesmo que a sua execução seja posterior a esse período.

\subsection{Cautelas fiscais}

A aplicação das cautelas fiscais pode ser adotada isolada ou cumulativamente. "É a própria circunstância do transporte e do acondicionamento da mercadoria que acabarão por recomendar a adoção de procedimentos cautelares, chegando ao próprio acompanhamento fiscal" (SOSA, 1995, p. 237).

No intuito de impedir a violação do veículo, da unidade de carga e dos volumes em trânsito aduaneiro serão aplicadas, pela autoridade administrativa que fará a liberação para o trânsito, dispositivos de segurança como lacração, cintagem e marcação e, sendo o caso, até mesmo acompanhamento fiscal. Estes dispositivos de segurança somente poderão ser rompidos em presença da fiscalização ou sob sua autorização.

A norma aduaneira visa a impedir que outros, que não a fiscalização de destino, rompam os lacres apostos na repartição de origem. Enfim, o que se proíbe é que os dispositivos de segurança sejam violados durante o trânsito.

\subsection{Rotas e prazos}

Ao dar início ao trânsito no local de origem, a autoridade administrativa cadastrará ou autorizará no sistema a rota e o respectivo prazo para a chegada do veículo com a carga no destino, de acordo com a via de transporte, podendo ambos serem propostos pelo transportador ou beneficiário.

10 2. Garantia: Obrigação que contrai, a favor da aduana, com objetivo de assegurar o pagamento dos gravames ou cumprimento de outras obrigações contraídas frente a ela. http://idg.receita.fazenda.gov.br/orientacao/aduaneira/ manuais/transito-aduaneiro/topicos/conceitos-e-definicoes acesso em: 10.10.2018. 
A expressão rota legal, como ponderada por SOSA (1996, p. 236), vem a significar o percurso a ser seguido, obrigatoriamente, pelo veículo transportador. É regra que tem aplicação mais encontradiça nos trânsitos terrestres rodoviários. A autoridade estabelece o percurso citando as rodovias a serem percorridas pelo veículo, podendo aceitar, a seu critério, rota alternativa proposta pelo interessado.

O trânsito terrestre deve, preferencialmente, ser realizado pelas vias principais, utilizandose, sempre que possível, o percurso mais direto. Os veículos terrestres utilizados no transporte de mercadoria estrangeira devem ser fechados, tipo baú, possibilitando a lacração, salvo se a mercadoria, por seu volume ou outra característica, o impedir, ou se for utilizado contêiner que ofereça segurança e inviolabilidade à mercadoria.

\subsection{Termo de responsabilidade}

Nosso direito positivo (Código Tributário Nacional, art. 121, parágrafo único, II) preceitua que o sujeito passivo da obrigação principal é a pessoa obrigada ao pagamento de tributo ou penalidade pecuniária. E acrescenta que o sujeito passivo diz-se: "II - responsável, quando, sem revestir a condição de contribuinte, sua obrigação decorra de disposição expressa em lei.” Em matéria aduaneira, a responsabilidade está fixada nos termos do Decreto-lei n ${ }^{\circ}$ 37/1966, compilado no Regulamento Aduaneiro.

A responsabilidade pelo cumprimento das obrigações fiscais suspensas em decorrência da aplicação do regime de trânsito aduaneiro será formalizada pelo transportador, em Termo de Responsabilidade para Trânsito Aduaneiro (TRTA), com validade de três anos, podendo ser renovado sucessivamente por igual período, e deverá ser apresentado à unidade de fiscalização aduaneira acompanhado de prova de poderes do signatário.

Esta formalização se fará no sistema, e nela o responsável declara assumir a condição de fiel depositário da mercadoria, enquanto subsistir a operação de trânsito aduaneiro.

\section{RESPONSABILIDADE TRIBUTÁRIA NO TRÂNSITO ADUANEIRO}

Após efetuado o desembaraço para trânsito pela autoridade aduaneira da unidade de origem, deverá a mercadoria ser transportada pela rota que lhe for estipulada para sua chegada ao destino, no prazo fixado e atendendo às cautelas necessárias à segurança fiscal.

No decorrer do percurso, pode ocorrer a interrupção do trânsito tanto por fatos alheios à vontade do transportador, como eventos extraordinários que comprometam a segurança do veículo ou do equipamento de transporte, bem como por determinação da autoridade fiscal, em casos de denúncia, suspeita ou conveniência da fiscalização. Estas ocorrências devem ser registradas ou, o transportador deverá comunicar o fato à unidade aduaneira com jurisdição sobre o local em que se encontra o veículo.

Ao término do trânsito aduaneiro, ou seja, quando o veículo chegar ao local de destino, deverá a autoridade administrativa atestar o horário de sua chegada e verificar a inviolabilidade 
dos elementos de segurança ou lacre aplicados na origem.

O término regular do regime "se verifica quando este produz seus efeitos normais que lhe são característicos, possibilitando a entrada da mercadoria em outro regime." (LOPES FILHO, 1984, p. 105). Se a mercadoria for objeto de despacho para consumo ou para entrada em outro regime especial, ou despacho de exportação, encerra-se o regime de trânsito, surgindo novo regime. Assim, o crédito tributário existente poderá extinguir-se, no caso específico do trânsito internacional ou de exportação; modificar-se, caso do despacho para consumo; ou persistir, na hipótese de mudança para outro regime.

Importante ressaltar, como já mencionado anteriormente, que a mercadoria não pode ter os dispositivos de segurança do seu transporte rompidos ou suprimidos e, que havendo extravio da mercadoria durante o percurso poderá acarretar a responsabilidade tributária, ressalvada a exceção disposta no artigo 664, do Regulamento Aduaneiro, ${ }^{11}$ no caso de a mercadoria não chegar ao local de destino por um caso fortuito ou força maior.

Constatados indícios de violação ou divergência, a unidade de destino procederá à verificação da carga, comparando-a com os documentos instrutivos do trânsito e com imagens de inspeção não invasiva na origem, se estiverem disponíveis, e informará o resultado no sistema. Ainda, a autoridade fiscal apurará o crédito tributário e informará no sistema a parcela referente aos impostos correspondentes ao extravio ou avaria.

No mesmo sentido do Regulamento Aduaneiro está a redação do $\S 1^{\circ}$, do artigo 74 , do

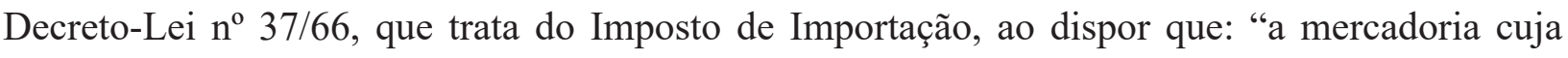
chegada ao destino não for comprovada ficará sujeita aos tributos vigorantes na data da assinatura do termo de responsabilidade."

O termo de responsabilidade será executado pela unidade que apurou o crédito tributário quando ficar configurado avaria ou extravio total ou parcial da carga transportada, no montante correspondente ao crédito apurado. No caso de nenhum dos veículos da operação de trânsito chegar ao destino, a apuração e as informações caberão à unidade de origem.

Como visto, o Regulamento Aduaneiro, em seu artigo 337, determina que: "As obrigações fiscais relativas à mercadoria, no regime de trânsito aduaneiro, serão constituídas em termo de responsabilidade firmado na data do registro da declaração de admissão no regime, que assegure sua eventual liquidação e cobrança.", sendo que, caso a mercadoria não seja apresentada no local de destino, na forma e prazo fixado, ficará o transportador "[...] sujeito ao cumprimento das obrigações assumidas no termo de responsabilidade, sem prejuízo das penalidades cabíveis." (art. $339, \S 1^{\circ}$, Regulamento Aduaneiro) e os tributos serão os vigentes à data da assinatura do termo de responsabilidade, com os devidos acréscimos legais, conforme consta no $\$ 2^{\circ}$, do citado artigo.

Cumpre frisar que, a depender do tipo da mercadoria importada, atualmente, os tributos incidentes na importação de mercadoria estrangeira, nos moldes do regime comum ou especial, são os seguintes:

11 Art. 664. A responsabilidade a que se refere o art. 660 pode ser excluída nas hipóteses de caso fortuito ou força maior. 
a) Imposto de Importação - II

b) Imposto sobre Produtos Industrializados - IPI;

c) Contribuição para o PIS/PASEP e COFINS;

d) Adicional de Frete para a Renovação da Marinha Mercante - AFRMM;

e) CIDE-Combustíveis;

f) Imposto sobre Circulação de Mercadorias e Serviços - ICMS;

g) Taxa de Utilização do Siscomex.

O vínculo obrigacional surge, segundo o $\mathrm{CTN}$, "no âmbito da relação tributária, entre sujeitos ativo e passivo; este, embora possa ser o contribuinte, poderá, também, ser terceira pessoa (art. 121, parágrafo único)" (SCHOUERI, 2018, p. 568).

A carga fiscal pode ser exigida de pessoa diferente daquela que praticou o fato gerador, sendo estabelecidos critérios norteadores desse procedimento para que o aplicador não se depare com um verdadeiro caos tributário, propiciando interpretações diferenciadas e equivocadas qualificações. Além dos contribuintes (sujeitos por dívida própria), também podem ser considerados no pólo passivo os responsáveis (sujeitos por dívida alheia) (MELO, 2012, p. 17).

Assim, o sujeito passivo é o sujeito que está obrigado ao pagamento do tributo, que será o contribuinte ou o responsável, consoante o determinado no Código Tributário Nacional. Mas nem sempre o contribuinte será aquele que deverá adimplir a obrigação, já que a lei pode eleger um terceiro como tal, excluindo a obrigação do contribuinte. Este será o responsável.

No caso em comento, consta do artigo 660, do Regulamento Aduaneiro, em seu $\S$ $2^{\circ}$, que os créditos tributários serão lançados de ofício, exceto na hipótese de o importador ou responsável assumir espontaneamente o pagamento, conforme se vê:

Art. 660. Os créditos relativos aos tributos e direitos correspondentes às mercadorias extraviadas na importação, inclusive multas, serão exigidos do responsável por meio de lançamento de ofício, formalizado em auto de infração, observado o disposto no Decreto $\mathrm{n}^{\mathrm{o}} 70.235$, de 1972.

$\S 1^{\circ}$ Para os efeitos do disposto no caput, considera-se responsável:

I - o transportador, quando constatado o extravio até a conclusão da descarga da mercadoria no local ou recinto alfandegado, observado o disposto no art. 661; ou II - o depositário, quando o extravio for constatado em mercadoria sob sua custódia, em momento posterior ao referido no inciso I.

$\S 2^{\circ}$ Fica dispensado o lançamento de ofício de que trata o caput na hipótese de o importador ou de o responsável assumir espontaneamente o pagamento dos créditos.

Verifica-se, pois, que na conclusão do Trânsito Aduaneiro, sendo observado o extravio de mercadorias durante o trânsito, o crédito tributário a elas referente será exigido do responsável, por 
meio de lançamento de ofício, salvo se o importador ou o responsável espontaneamente assumir o pagamento dos créditos.

Também será considerado responsável o depositário na hipótese de o extravio ter sido constatado em mercadoria sob sua custódia. Esta hipótese não se aplica ao Trânsito Aduaneiro.

A seguir, o artigo 661 indica em que circunstâncias o transportador será o responsável pelo pagamento do crédito tributário. In verbis:

Art. 661. Para efeitos fiscais, é responsável o transportador quando:

I - constatado que houve, após o embarque, substituição de mercadoria;

II - houver extravio de mercadoria em volume descarregado com indícios de violação;

III - o volume for descarregado com peso ou dimensão inferior ao constante no conhecimento de carga, no manifesto ou em documento de efeito equivalente.

(grifo nosso)

Destarte, para efeitos fiscais, o transportador será responsável quando, após o embarque, a mercadoria houver sido substituída ou houver sido extraviada em volume descarregado com indícios de violação; ou, ainda, quando o volume descarregado apresentar peso ou dimensão inferior ao constante no documento que instruiu o pedido de concessão do regime especial de Trânsito Aduaneiro.

\section{PENALIDADESADMINISTRATIVAS E FISCAIS APLICÁVEISAOTRANSPORTADOR}

O Poder Público, por intermédio do Poder de Polícia da Administração Pública, em nome da coletividade, pode interferir na esfera particular, estabelecendo infrações administrativas e suas respectivas penalidades.

Infringir uma lei é não atender ao seu comando; é agir de forma diferente à conduta por ela estipulada, seja por ignorá-la e, portanto, sem intenção, seja com o objetivo de conseguir uma vantagem ou evitar um prejuízo para si ou para outra pessoa. A legislação tributária contempla não só o fazer, mas também o deixar de fazer alguma coisa estabelecida pela norma legal.

Prescreve o Código Tributário Nacional, em seu artigo 97, inciso V, que somente a lei pode estabelecer a cominação de penalidade para as ações ou omissões contrárias a seus dispositivos, ou para outras infrações nela definidas. Desta leitura, infere-se que a definição das infrações tributárias na esfera aduaneira e a cominação das correspondentes penalidades também devem obedecer ao princípio da legalidade.

A respeito dos atos de fiscalização, o jurista José dos Santos Carvalho Filho (2007, p. 77) já apontou:

Não adianta deter o Estado o poder de impor restrições aos indivíduos se não dispusesse de mecanismos necessários à fiscalização da conduta deste. Assim, o poder de polícia reclama do Poder Público a atuação de agentes fiscalizadores da conduta dos indivíduos.

A fiscalização apresenta duplo aspecto: um preventivo, através do qual os agentes 
da Administração procuram impedir um dano social, e um repressivo, que, em face da transgressão da norma de polícia, redunda na aplicação de uma sanção.

Dessa forma, a Instrução Normativa da Secretaria da Receita Federal $n^{\circ}$ 248, de 25 de novembro de 2002, com alterações posteriores, ao tratar da aplicação do regime de trânsito aduaneiro, estabelece, no artigo 72, as ocorrências que, caso venham se dar no curso das operações de trânsito, serão registradas no sistema para o transportador, e sua respectiva gradação, conforme se vê:

Art. 72. No curso das operações de trânsito serão registradas no sistema, as seguintes ocorrências para o transportador, com a respectiva gradação:

I - automaticamente:

a) a) chegada do veículo fora do prazo estabelecido, por ação ou omissão do transportador, leve;

b) violação de dispositivo de segurança, unidade de carga ou veículo, média; e

c) extravio parcial ou total de carga, grave;

II - pelo Auditor-Fiscal da Receita Federal do Brasil:

a) desvio da rota autorizada, sem motivo justificado, média;

b) substituição do veículo transportador, sem autorização da autoridade aduaneira, média; e

c) chegada do veículo em unidade da SRF diversa da unidade de destino indicada na declaração, média.

$\S 1^{\circ} \mathrm{O}$ transportador será responsabilizado pelas ocorrências a que der causa, bem assim por aquelas a que derem causa seus prepostos, empregados, contratados ou subcontratados.

$\S 2^{\circ}$ A ocorrência será agravada, mediante formalização de processo administrativo, no caso de dolo do transportador.

O transportador será responsabilizado pelas ocorrências que der causa, bem assim por aquelas a que derem causa seus prepostos, empregados, contratados ou subcontratados. Em caso de dolo do transportador, a ocorrência será agravada, mediante formalização de processo administrativo.

No que se refere às penalidades previstas no Regulamento Aduaneiro, o artigo 675, estabelece:

Art. 675 - As infrações estão sujeitas às seguintes penalidades, aplicáveis separada ou cumulativamente:

I - perdimento do veículo;

II - perdimento da mercadoria;

III - perdimento de moeda;

IV - multa; e

$\mathrm{V}$ - sanção administrativa.

O perdimento do veículo ocorrerá nas hipóteses de o veículo estar em situação ilegal quanto às normas que o habilitem a exercer a navegação ou transporte internacional, correspondente à sua 
espécie; quando efetuar operação de descarga de mercadoria estrangeira ou carga de mercadoria nacional ou nacionalizada fora do porto, aeroporto ou outro local para isso habilitado; quando o veículo terrestre utilizado no trânsito de mercadoria estrangeira desviar-se de sua rota legal sem motivo justificado ou ainda quando o veículo for considerado abandonado.

Outra modalidade de penalidade é a denominada pena de perdimento da mercadoria. No que se refere ao trânsito aduaneiro, em operação de carga, ou já carregada em qualquer veículo ou dele descarregada ou em descarga, sem ordem, despacho ou licença, por escrito da autoridade aduaneira, ou sem o cumprimento de outra formalidade essencial estabelecida no texto normativo. Se a mercadoria estiver incluída em lista de sobressalentes e provisões de bordo e estiver em desacordo com as necessidades de serviço e do custeio do veículo e da manutenção de sua tripulação, também será objeto de pena de perdimento.

Estes são apenas alguns casos dos muitos relacionados no artigo 689 (Decreto-lei nº 37/66 e alterações posteriores) que elencam os casos em que a pena de perdimento de mercadoria poderá ser aplicada.

O Auditor-Fiscal da Receita Federal do Brasil irá propor a penalidade adequada que se encaixe nas condutas tipificadas nos artigos 688 a 735-C, do Regulamento Aduaneiro e, no caso de a mercadoria não chegar ao local de destino, configurando desvio de rota legal e extravio, o titular da Receita Federal da unidade de destino comunicará o fato referido à autoridade policial competente, para efeito de apuração do crime de contrabando ou de descaminho, conforme dispõe o $\S 4^{\circ}$, do artigo 688 .

Há que se mencionar que o transportador poderá praticar os crimes contra a ordem tributária omitindo informações, prestando declarações falsas às autoridades fazendárias e mediante outras condutas descritas no art. $1^{\circ}$, da Lei $n^{\circ} 8.173 / 90$. Neste caso, poderá responder judicialmente pelo crime cometido.

\section{CONCLUSÃO}

A legislação aduaneira é complexa e, muitas vezes tem gênese nos costumes do comércio internacional, conhecidos apenas aos iniciados. Em sua imensa maioria, o sub-sistema normativo aduaneiro é formado, como aponta Folloni (2005, p. 14) por instrumentos normativos secundários, de hierarquia infralegal e, conhecer cada um destes atos é indispensável ao profissional do ramo. Além disso, estes instrumentos normativos se sucedem com frequência impressionante, o que faz com que as publicações existentes se tornem ultrapassadas rapidamente.

Poucos são os trabalhos jurídicos nesta área de legislação aduaneira e os estudos realizados por juristas são raros e, não raro, ainda, observar que não foram objeto de atualização. No entanto, são extremamente louváveis por serem um estudo sistemático desta temática tão importante quanto indispensável no mundo moderno.

Em especial, acerca do tema Trânsito Aduaneiro, há que se dizer ser ele vasto e, que existe pouca doutrina disponível em livros e manuais, sendo, muitas vezes, a internet uma importante ferramenta para a busca de informações, através de estudos publicados a respeito do assunto. 
Vale ressaltar que o Trânsito Aduaneiro é bastante útil para importadores situados em países limítrofes com o Brasil, como Paraguai e a Bolívia, que não dispõem de portos marítimos próprios e precisam atravessar suas mercadorias pelo nosso território, seja por via rodoviária ou aérea e, com a aplicação desse Regime Aduaneiro Especial recebem o benefício da suspensão tributária temporária para essa passagem. E, também, é útil para a movimentação de mercadoria da zona primária para um recinto alfandegado na zona secundária.

Serve o referido regime aduaneiro de incremento das exportações e aumento da competitividade do produto final no mercado externo. No entanto, na mesma proporção em que o Trânsito Aduaneiro é relevante aos beneficiários, há necessidade de o Brasil seguir rigorosamente seu papel de fiscalização e controle sobre essas mercadorias de passagem, evitando, assim, que ingresse no país material proibido (contrabando) ou que durante o trânsito, haja o descaminho de mercadorias.

Destarte, será o transportador responsável pela mercadoria despachada em Trânsito Aduaneiro que não chegue a seu destino, ou ainda que seja objeto de perda ou avaria, podendo sofrer a penalidade de perda do veículo, perda da mercadoria, além das multas previstas na importação, dentre outros casos, no de uso de falsidade nas provas, ou ainda na transferência a terceiros de mercadorias não desembaraçadas.

Embora pouco contribuindo para o incremento dos cofres públicos do nosso país, vez que a mercadoria que transita em nosso território não integra a riqueza nacional, o Regime Aduaneiro Especial de Trânsito Aduaneiro, engrandece nossas relações na política e no respeito perante o comércio exterior.

\section{REFERÊNCIAS}

BRASIL. DECRETO n 6.759, de 5 de fevereiro de 2009. Disponível em: < http//www. planalto.gov.br/ccivil03/ato2007-2010/2009/decreto/d6759.htm>. Acesso em: 01 out. 2018.

BRASIL. DECRETO-LEI no 37, de 18 de novembro de 1966. Disponível em: < $\underline{\text { http://www. }}$ planalto.gov.br/ccivil 03/decreto-lei/Del0037.htm>. Acesso em: 01 out. 2018.

BRASIL. LEI n ${ }^{0}$ 5.172, de 25 de outubro de 1966. Disponível em: $<\underline{\text { http: } / / \text { www.normaslegais. }}$ com.br/legislacao/lei5172-1966-codigo-tributario-nacional-ctn.htm> Acesso em: 12 out. 2018.

BRASIL. Receita Federal do Brasil. Instrução Normativa SRF no 248, de 25 de novembro de 2002. Disponível em: $<$ http://normas.receita.fazenda.gov.br/sijut2consulta/link. action?idAto $=15125 \&$ visao $=$ anotado $>$. BRASIL. Receita Federal do Brasil. Instrução Normativa SRF no 1.741, de 22 de setembro de 2017. Disponível em: <http://normas.receita.fazenda.gov.br/sijut2consulta/link. action? idAto $=86521 \&$ visao $=$ relacional $>$. Acesso em: 05 out. 2018.

BRASIL. Receita Federal do Brasil. Instrução Normativa RFB n ${ }^{0} 1.598$, de 09 de dezembro de 2015. Disponível em: $<$ http://normas.receita.fazenda.gov.br/sijut2consulta/link. action?visao=anotado\&idAto=70204\# 1587887>. Acesso em: 01 de mai. 2018. 
1996.

CARVAlHO FILHO, José dos Santos. Manual de Direito Administrativo. Rio de Janeiro: Lumen Juris, 2007.

DIALLO, Alfa Oumar. Tributação do Comércio Brasileiro e Internacional. São Paulo: Método, 2001.

FOLLONI, André Parmo. Tributação sobre o Comércio Exterior. São Paulo: Dialética, 2005.

LOPES FILHO, Osíres de Azevedo. Regimes aduaneiros especiais. São Paulo: RT, 1984.

MARINS, James. Direito processual tributário brasileiro: administrativo e judicial. 10. ed. rev. atual. e ampl. São Paulo: Revista dos Tribunais, 2017.

MEIRA, Liziane Angelotti. Regimes Aduaneiros Especiais. São Paulo: IOB, 2002.

MELO, José Eduardo Soares de. A Importação no Direito Tributário: Impostos, Taxas, Contribuições. São Paulo: Revista dos Tribunais, 2012.

PAULSEN, Leandro. Curso de Direito Tributário. 9. ed., São Paulo: Saraiva Educação, 2018.

SCHOUERI, Luís Eduardo. Direito Tributário. 8. ed. São Paulo:Saraiva, 2018.

SOSA, Roosevelt Baldomir. A Aduana e o Comércio Exterior. São Paulo: Aduaneiras, 1996.

SOSA, Roosevelt Baldomir. Comentários à Lei Aduaneira. São Paulo: Aduaneiras, 1995.

Como citar: BOTELHO, Glacy Odete Rachid. CAMPOS, Sinara de Freitas Elias. Responsabilidade do transportador por infrações no transporte aduaneiro. Scientia Iuris, Londrina, v. 24, n. 1, p. 186-203, mar. 2020. DOI 10.5433/21788189.2020v24n1p186. ISSN 2178-8189.

Recebido em: 18/03/2019

Aprovado em: 24/11/2019 